\title{
Aktivitas Enzim Inulinase dan Laju Pertumbuhan Spesifik Isolat Bakteri IS-1 Pada Medium Tepung Umbi Dahlia
}

\author{
WIJANARKA ${ }^{1}$, MAULIDA AQLINA ${ }^{2}$, KRISTINA ${ }^{2}$ \\ ${ }^{1}$ Dosen Biologi Fakultas Sains dan Matematika, Universitas Diponegoro, Semarang, Jawa Tengah. \\ ${ }^{2}$ Mahasiswa Biologi, Fakultas Sains dan Matematika, Universitas Diponegoro, Semarang. \\ Diterima: 30 Mei 2018 - Disetujui: 18 September 2018 \\ (C) 2018 Jurusan Biologi FMIPA Universitas Cenderawasih
}

\begin{abstract}
Dahlia bulbs (Dahlia variabilis) contains carbohydrates in the form of inulin. Inulin is a form of fructose polymer from fructose monomers. Inulin hydrolysis produces a product in the form of fructose.Inulinase enzyme is an enzyme able to purely hydrolyze inulin. This study aims to determine the activity of inulinase enzymes and the specific growth rate of IS_1 bacterial isolates producing inulinase in medium of Dahlia tuber flour. Isolates of inulinase-producing bacteria were isolated directly from decay dahlia tubers and used as an inoculum in creating starter.The measurement of cell growth was carried out by inoculating a 20-hour starter on the production medium. Incubation is done for 24 hours using a rotary shaker with a speed of $120 \mathrm{rpm}$. Sampling was carried out every 4 hours at 0-hour (T0), 4 hours (T4), 8 hours (T8), 12 hours (T12), 16 hours (T16), 20 hours (T20) and 24 hours (T24) intervals with a sample of $5 \mathrm{~mL}$ measured for absorbance of $\lambda 520 \mathrm{~nm}$ using spectrophotometer. Production medium culture in each sample was taken $1 \mathrm{~mL}$ and centrifuged at $3000 \mathrm{rpm}$ for 10 minutes to obtain supernatant of crude enzyme. Measurement of inulinase enzyme activity was carried out using 3,5-dinitrosalicylic acid (DNS) method and spectrophotometric method at $\lambda 570 \mathrm{~nm}$. IS_1 bacterial isolate showed optimum growth at incubation time of 8 hours with OD of 0.647 and had a specific growth rate $(\mu)$ of 0.02 / hour with a generation time of 34.65 hours. The highest enzyme activity produced by IS_1 bacteria at 8 hours incubation time was 0.490 IU. The conclusion of this study is that IS_1 bacteria indicates good growth in medium of dahlia tuber flour and has inulinase enzyme activity which is able to hydrolyze inulin into fructose.
\end{abstract}

Key words: inulin, bacterial isolate, inulinase, production.

\section{PENDAHULUAN}

Tanaman dahlia (Dahlia variabilis) termasuk ke dalam famili Compositae, yaitu tanaman bunga hias yang menghasilkan karbohidrat dan disimpan dalam bentuk umbi. Baik bunga dan umbinya dapat dimanfaatkan secara komersial. Bunga dahlia mekar sepanjang tahun. Morfologi tumbuhan dahlia yaitu batang tegak bercabang,

\footnotetext{
* Alamat korespondensi:

Departemen Biologi, Fakultas Sains dan Matematika, Universitas Dionegoro. Jl. Prof. Soedarto SH, Tembalang, Semarang, Jawa Tengah. Telp./fax.: +622470799494.

E-mail: wikasmara@yahoo.com
}

daun bertoreh berwarna hijau dan letaknya bersebelahan. Pada puncak perkembangan tumbuhan, pucuk tangkai mengeluarkan bunga dengan beragam warna (Massolo, 2016). Menurut Pandiyan et al. (2012), tanaman dahlia merupakan salah satu jenis tanaman yang banyak tumbuh di Indonesia dan mengandung inulin dalam jumlah cukup tinggi. Selain bunganya indah, umbinya juga dapat dimanfaatkan sebagai sumber inulin. Di Indonesia umbi bunga dahlia sampai saat ini belum bisa dimanfaatkan secara optimal dan masih merupakan limbah yang dihasilkan oleh petani bunga potong. Inulin diproduksi secara komersial dari umbi tanaman chicory (Cichorium intybus L.) di luar negeri, namun tanaman ini tidak 
ditemukan di Indonesia. Selain itu, inulin belum diproduksi di Indonesia, sehingga kebutuhan inulin untuk industri dan untuk penelitian masih diimpor.

Inulin ialah bentuk polimer fruktosa dari monomer-monomer fruktosa. Hidrolisis inulin menghasilkan produk berupa fruktosa (Susilowati, 2013). Tanaman yang mengandung inulin umumnya berasal dari golongan Liliaceae, seperti daun bawang, bawang merah, bawang putih, dan asparagus; dan Compositae, seperti Jerusalem artichoke, dahlia, chicory, dan yacon. Dua spesies yang saat ini digunakan oleh industri untuk memproduksi inulin berasal dari golongan Compositae, yaitu Jerusalem artichoke (Helianthus tuberosus) dan chicory (Cichorium intybus) (Gibson \& Delzenne, 2008). Tanaman chicory dan artichoke tumbuh baik di Amerika Utara sedangkan tanaman dahlia dapat tumbuh baik di dataran tinggi Indonesia. Pada umbi dahlia kadar inulin yang terdapat di dalamnya cukup besar yaitu sekitar 65,7 \% berat kering (Ma'aruf, 2011).

Inulinase merupakan enzim hidrolase yang mampu menghidrolisis inulin menjadi inulooligosakarida (IOS) dengan memotong satuan fruktosa dari inulin pada posisi terminal $\beta$ 2,1. Jumlah inulinase yang diproduksi dapat ditentukan dengan uji aktivitas enzim (Dixon \& Webb, 1979; Singh \& Gill, 2006). Enzim inulinase dapat diisolasi dari umbi dahlia, jerusalem artichoke, chicory, dan dandelion, namun aktivitas yang dihasilkan relatif rendah dibandingkan dengan inulinase yang diisolasi dari mikrobia. Mikrobia penghasil inulinase dapat diisolasi dari tanah sekitar umbi dahlia dan perakaran tanaman yang mengandung inulin. Enzim inulinase dari mikrobia lebih potensial sebagai penghasil enzim, karena pertumbuhan mikrobia yang relatif lebih cepat (Susilowati, 2013).

Pertumbuhan merupakan suatu pertambahan bagian-bagian sel. Adanya pertumbuhan sel dapat diketahui dengan adanya pertambahan ukuran dan pembelahan sel. Proses pertumbuhan yaitu proses dinamik dan kinekita yang dapat digunakan untuk melihat atau memprediksi produksi biomassa/produk yang dihasilkan selama proses fermentasi. Faktor utama yang mempengaruhi pertumbuhan dan perilaku mikroba salah satunya ialah media/sumber karbon sebagai sumber dasar. Produk fermentasi merupakan hasil dari metabolit primer maupun metabolit sekunder. Enzim merupakan hasil dari metabolit primer (Wijanarka et al., 2013a). Pertumbuhan bakteri pada umumnya ditandai dengan empat fase yang khas, yakni periode awal yang tampaknya tanpa pertumbuhan (fase lamban atau lag phase) diikuti oleh suatu periode pertumbuhan yang cepat (fase log), kemudian mendatar (fase statis atau stationary phase), dan akhirnya diikuti oleh suau penurunan polpulasi sel-sel hidup (fase kematian atau penurunan) (Sumarsih, 2003).

\section{METODE PENELITIAN}

\section{Sumber Mikroorganisme}

Mikroba yang digunakan dalam penelitian ini diisolasi langsung dari umbi dahlia yang sudah busuk.

\section{Pembuatan larutan tepung umbi dahlia}

Umbi dahlia mula-mula dicuci bersih, kemudian dikupas, dipotong kecil-kecil, dikeringkan di bawah sinar matahari selama 3-4 hari, dan dihaluskan hingga menjadi tepung. Diambil 9 gram tepung umbi dahlia yang sudah halus dilarutkan dalam akuadest sebanyak $300 \mathrm{~mL}$, kemudian dipanaskan hingga tepung larut dan disaring menggunakan kapas terlebih dahulu dilanjutkan dengan menggunakan kertas saring hingga tidak didapatkan endapan tepung umbi.

\section{Pembuatan media selektif inulin}

Media selektif inulin merupakan media berkonsistensi padat dengan komposisi yang terdiri dari agar 0,85 gram, inulin murni 0,5 gram yang kemudian dilarutkan dengan akuadest 50 $\mathrm{mL}$ pada erlenmeyer di dalam microwave oven. Larutan dibagi ke dalam 6 tabung reaksi sebagai media kultivasi, masing-masing 3 tabung reaksi untuk bakteri dan 3 tabung reaksi untuk yeast. Sisa larutan dalam erlenmeyer dan larutan pada 6 tabung reaksi tadi disterilisasi dalam autoklaf 
dengan suhu $121^{\circ} \mathrm{C}$ selama 15 menit. Sisa larutan pada erlenmeyer kemudian dituangkan pada dua cawan petri steril sebagai media isolasi mikroba penghasil enzim inulinase.

\section{Pembuatan media produksi}

Tahap pembuatan media produksi dibuat dengan komposisi $(\mathrm{g} / \mathrm{L})$ yang terdiri dari larutan tepung umbi dahlia $150 \mathrm{~mL}, \mathrm{NH}_{4} \mathrm{NO}_{3}(0,345)$, $\left(\mathrm{NH}_{4}\right)_{2} \mathrm{HPO}_{4}(0,555), \mathrm{K}_{2} \mathrm{HPO}_{4}(0,15), \mathrm{MgSO}_{4} .7 \mathrm{H}_{2} \mathrm{O}$ $(0,075)$, yeast extract $(0,225)$, kemudian larutan dihomogenkan dan dibagi ke dalam 2 erlenmeyer masing masing $50 \mathrm{~mL}$ untuk media produksi enzim, kemudian sisa larutan dibagi ke dalam 2 tabung reaksi sebanyak $3 \mathrm{~mL}$ sebagai media starter, dan 2 tabung reaksi lainnya sebanyak $5 \mathrm{~mL}$ untuk blanko pengukuran pertumbuhan OD. Media produksi disterilisasi dalam autoklaf dengan suhu $121^{\circ} \mathrm{C}$ selama 15 menit.

\section{Pembuatan buffer sodium asetat $0.1 \mathrm{M}$ pH 5}

Buffer sodium asetat dibuat dengan komposisi (g/L) yang terdiri dari $\mathrm{CH}_{3} \mathrm{COONa}(1,23)$, akuadest steril $100 \mathrm{~mL}, \mathrm{CH}_{3} \mathrm{COOH}$ glasial $100 \%$ yang ditambahkan sedikit demi sedikit hingga $\mathrm{pH}$ larutan menjadi 5. Buffer disterilisasi dalam autoklaf dengan suhu $121^{\circ} \mathrm{C}$ selama 15 menit.

\section{Pembuatan reagen DNS}

Reagen DNS dibuat dengan komposisi (g/L) yang terdiri dari asam dinitrosalisilat $(0,175)$, sodium kalium tartat $(32,5), \mathrm{NaOH}(2,0)$ dan 100 $\mathrm{mL}$ akuadest. Semua bahan dicampur dalam erlenmeyer steril, larutan DNS yang sudah jadi tidak perlu disterilisasi.

\section{Isolasi mikroba penghasil enzim inulinase}

Isolasi mikroba penghasil enzim inulinase dilakukan dengan metode streak, sebanyak satu ose suspensi mikroba dari umbi dahlia yang sudah busuk distreak ke dalam cawan petri yang berisi media selektif inulin, kemudian diinkubasi selama 2 hingga 3 hari pada suhu ruangan. Koloni yang tumbuh kemudian dikultivasi untuk menjadi kultur murni pada media selektif inulin agar miring dan diinkubasi selama 2 hari pada suhu ruangan.

\section{Pembuatan starter}

Starter dibuat dengan menginokulasikan bakteri sebanyak satu ose secara aseptik ke dalam masing-masing media produksi steril dalam tabung reaksi, kemudian diagitasi pada Rotary Shaker dengan kecepatan $120 \mathrm{rpm}$ dalam suhu ruang selama 20 jam. Hasil kultur bakteri yang tumbuh dicirikan dengan media produksi yang menjadi keruh.

\section{Produksi enzim}

Kultur bakteri pada starter setelah 20 jam dipanen, kemudan diinokulasikan pada masingmasing medium produksi steril dalam erlenmeyer, kemudian diagitasi pada Rotary Shaker dengan kecepatan $120 \mathrm{rpm}$ dalam suhu ruang. Pemanenan enzim dilakukan per-4 jam, dimulai pada jam ke-0 (setelah pemanenan starter), ke-4, ke-8, ke-12, ke16 , ke-20 dan ke-24. Sampel diambil secara aseptis ke dalam tabung sampel untuk dilakukan pengukuran pertumbuhannya.

\section{Pengukuran pertumbuhan}

Kultur bakteri pada starter setelah 20 jam dipanen, diinokulasikan pada masing-masing medium produksi steril dalam erlenmeyer, kemudian diagitasi pada Rotary Shaker dengan kecepatan $120 \mathrm{rpm}$ dalam suhu ruang. Tiap 4 jam, kultur dalam erlemeyer diambil sampel secara aseptis dan diukur optical density (OD) dengan menggunakan spektrofotometer dengan panjang gelombang $520 \mathrm{~nm}$.

Menurut Metcalf \& Eddy (2003), nilai $\mu$ merupakan nilai laju pertumbuhan spesifik pada fase eksponensial. Nilai koefisien $\mu$ menunjukkan kecepatan pertumbuhan mikroorganisme. Laju pertumbuhan eksponensial dapat didefinisikan sebagai (1)

$$
\frac{d X}{d t}=\mu X
$$

dengan $X$ adalah konsentrasi biomassa (mg/L). Apabila nilai $\mu$ konstan, maka integrasi dari persamaan di atas akan menjadi persamaan sebagai berikut:

$$
\ln X=\mu \cdot t+\ln X_{0}
$$


dengan $\mathrm{X}_{0}$ merupakan konsentrasi biomassa (mg/L) saat $\mathrm{t}=0$. Nilai $\mu$ merupakan slope dari hubungan $\ln X$ terhadap waktu. Kemudian waktu generasi (g) merupakan waktu yang diperlukan untuk membelah diri dari satu menjadi dua sel sempurna.

$$
\mathrm{g}=\frac{0, \overline{6} 93}{\mu}
$$

\section{Pemanenan enzim}

Kultur bakteri pada starter setelah 20 jam dipanen, diinokulasikan pada masing-masing medium produksi steril dalam erlenmeyer, kemudian diagitasi pada Rotary Shaker dengan kecepatan $120 \mathrm{rpm}$ dalam suhu ruang. Pemanenan enzim dilakukan per 4 jam, dimulai pada ke-0 (setelah pemanenan starter), ke-4, ke-8, ke-12, ke16 , ke-20 dan ke-24. Sampel diambil secara aseptis untuk disentrifugasi pada centrifuge dengan kecepatan 100 rpm selama 10 menit. Hasil sentrifugasi yang didapatkan berupa pelet dan crude enzyme. Crude enzyme digunakan untuk uji aktivitas enzim.

\section{Uji aktivitas enzim}

Sebanyak 4 buah tabung reaksi disiapkan untuk masing-masing perlakuan dengan label ES (Enzim-Substrat), S (Substrat inulin), E (Crude Enzyme) dan blanko. Tabung ES dimasukkan 0,5 $\mathrm{mL}$ substrat inulin murni $1 \%, 0,4 \mathrm{~mL}$ buffer sodium asetat $0,1 \mathrm{M}$ pH 5 dan 0,1 mL crude enzyme; tabung $\mathrm{S}$ dimasukkan $0,5 \mathrm{~mL}$ substrat inulin murni $1 \%, 0,4 \mathrm{~mL}$ buffer sodium asetat $0,1 \mathrm{M}$ pH 5 dan $0,1 \mathrm{~mL}$ akuadest steril; tabung E dimasukkan $0,4 \mathrm{~mL}$ buffer sodium asetat, $0,1 \mathrm{~mL}$ crude enzyme dan $0,5 \mathrm{~mL}$ akuadest steril; dan tabung blanko diisi $0,4 \mathrm{~mL}$ buffer sodium asetat dan $0,6 \mathrm{~mL}$ akuadess steril. Semua tabung diinkubasikan dalam oven pada suhu $50{ }^{\circ} \mathrm{C}$ selama 30 menit. Reaksi dimatikan dengan air mendidih \pm 2 menit dan ditunggu hingga larutan hangat-hangat kuku, kemudian ditambahkan $1 \mathrm{~mL}$ reagen DNS dan dipanaskan kembali selama \pm 2 menit, ditambahkan $5 \mathrm{~mL}$ akuadest dan diukur absorbansinya dengan menggunakan spektrofotometer dengan panjang gelombang $570 \mathrm{~nm}$. Aktivitas enzim dinyatakan dalam satuan
Internasional Unit (IU), dimana 1 unit aktivitas enzim berarti sejumlah enzim mampu membebaskan produk sebanyak $1 \mu \mathrm{mol}$ per menit. Aktivitas inulinase dapat ditentukan menurut rumus (Bonciu et al., 2010; Park \& Yun, 2001; Wijanarka et al., 2013b).

Aktivitas Enzim (IU) =

$$
\frac{(\text { AbsES - AbsE - AbsS). fruktosa }}{\text { BMf . } t} \times P \times 1000
$$

dimana:

Abs ES = absorbansi enzim substrat;

Abs E = absorbansi enzim;

Abs ES = absorbansi enzim substrat;

Abs $S=$ absorbansi substrat;

$\mathrm{BM} f=$ berat molekul fruktosa $(180,1 \mathrm{gr} / \mathrm{mol})$;

$\mathrm{P}=$ faktor pengenceran $(50 \mathrm{x})$;

$\mathrm{t}=$ waktu inkubasi selama 30 menit; dengan persamaan regresi kurva fruktosa standar $Y_{\text {fruktosa }}=-0,0288+0.5398 X_{\text {nilai OD. }}$

\section{HASIL DAN PEMBAHASAN}

\section{Isolasi mikroba penghasil enzim inulinase}

Mikroba yang digunakan dalam penelitian ini diisolasi langsung dari umbi dahlia yang sudah busuk, dengan harapan mikroba tersebut merupakan mikroba yang mampu menghasilkan enzim inulinase. Hal ini didasarkan bahwa umbi dahlia mengandung sumber inulin dimana menurut Dewi (2016), kandungan inulin pada umbi bunga dahlia sebesar 69,50-75,48\% dari berat kering umbi. Menurut Susilowati (2013), mikrobia penghasil inulinase dapat diisolasi dari tanah sekitar umbi dahlia dan perakaran tanaman yang mengandung inulin.

Hasil isolasi menunjukkan bahwa koloni yang tumbuh pada media selektif merupakan koloni bakteri. Sebanyak 3 isolat bakteri diambil dari 3 koloni yang tumbuh terpisah kemudian dikultivasi pada media agar miring dengan komposisi media yang sama, ternyata yang mampu tumbuh dengan baik adalah isolat bakteri 1 dan 3 (IS_1 dan IS_3). Isolat bakteri IS_1 dan IS_3 inilah yang akan diukur laju pertumbuhan spesifik dan aktivitas enzimnya. 


\section{Pertumbuhan isolat bakteri IS_1}

Fermentasi secara batch culture isolat bakteri IS_1 dilakukan pada media produksi cair yang mengandung larutan tepung umbi dahlia, hal tersebut dikarenakan umbi dahlia mengandung sumber inulin dimana menurut Dewi (2016), kandungan inulin pada umbi dahlia sebesar $69,50-75,48 \%$ dari berat kering umbi. Menurut Wijanarka et al. (2013b), sumber karbon inulin yang terkandung di umbi dahlia dapat digunakan sebagai bioenergi dan biosintesis untuk proses pertumbuhan.

Uji laju pertumbuhan bakteri dilakukan untuk mengetahui sifat pertumbuhan bakteri melalui kurva pertumbuhan bakteri. Kurva pertumbuhan bakteri dibuat untuk mengetahui fase pertumbuhan bakteri yaitu fase lag, eksponensial, stasioner, dan kematian (Imron \& Purwanti, 2016). Berdasarkan hasil penelitian, pertumbuhan bakteri tertinggi terdapat pada waktu inkubasi 8 jam dengan nilai OD sebesar 0,647. Hal ini menunjukkan bahwa pertumbuhan bakteri IS_1 pada waktu tersebut memasuki fase logaritmik, dimana pada fase ini pertumbuhan bakteri berlangsung cepat, sel-sel membelah dan jumlahnya meningkat secara logaritma sesuai dengan pertambahan waktu disertai dengan meningkatnya produksi metabolit, sehingga aktivitas enzimnya dalam keadaan optimal. Hal ini sesuai dengan pendapat Reiny (2012) bahwa fase logaritmik menggambarkan sel membelah diri dengan laju yang konstan, masa menjadi dua kali lipat dengan laju sama, aktivitas metabolisme konstan, serta keadaan pertumbuhan seimbang. Selain itu, dalam penelitian ini dapat kita diketahui bahwa ternyata fase logaritmik dimulai pada jam ke-0 sampai jam ke-16 yang ditandai dengan munculnya nilai OD pada waktu inkubasi ke-0 hingga ke-16 jam, selanjutnya setelah jam tersebut diikuti fase stasioner. Hal tersebut disebabkan adanya starter yang diberikan pada medium pertumbuhan tersebut. Menurut Wijanarka et al. (2013a), adanya starter mengakibatkan bakteri langsung mengalami pertumbuhan log tanpa adaptasi dulu dengan lingkungan setempat (meniadakan fase lag dan pertumbuhan akan langsung memasuki fase eksponensial).

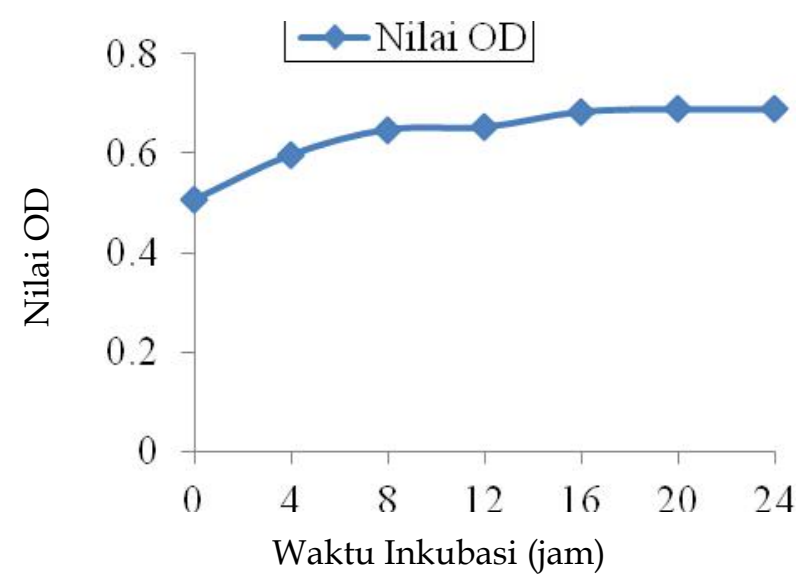

Gambar 1. Kurva Pertumbuhan Isolat Bakteri IS_1.

Penentuan kecepatan pertumbuhan spesifik berdasarkan atas pengamatan pertumbuhan pada rase logaritmik (Millis \& Pittard, 1992). Berdasarkan penelitian yang telah dilakukan, isolat bakteri IS_1 mempunyai kecepatan pertumbuhan spesifik $(\mu)$ sebesar 0,02/jam dengan waktu generasi sebesar 34,65 jam. Kecepatan pertumbuhan tersebut mencerminkan isolat bakteri IS_1 mempunyai kemampuan pertumbuhan yang berkaitan langsung dengan fase eksponensial serta produk metabolismenya (enzim inulinase). Namun nilai tersebut sangat rendah jika dibandingan dengan beberapa penelitian mengenai laju pertumbuhan spesifik mikroba penghasil inulinase. Hal ini mengindikasikan bahwa beberapa faktor pertumbuhan isolat IS_1 perlu diperbaiki untuk meningkatkan laju pertumbuhannya. Pertumbuhan dan metabolisme dalam proses fermentasi sangat dipengaruhi oleh faktor-faktor seperti suhu, $\mathrm{pH}$, kecepatan agitasi dan tingkat oksigen terlarut. Menurut Pribazari et al. (1996), nilai $\mu$ semakin besar seiring dengan meningkatnya konsentrasi substrat yang ditambahkan. Semakin besarnya nilai $\mu$ mengindikasikan semakin tingginya laju pertumbuhan mikroorganisme, dan nilai $\mu$ yang rendah menunjukkan pertumbuhan mikroorganisme yang lambat. Selain itu menurut Imron \& Purwanti (2016) diketahui bahwa semakin tinggi laju pertumbuhan spesifik bakteri semakin 
rendah waktu generasi bakteri. Laju pertumbuhan spesifik untuk setiap bakteri berbeda-beda. Hal ini disebabkan karena kandungan enzim pada masing-masing bakteri berbeda yang mempengaruhi proses metabolisme bakteri.

\section{Aktivitas enzim inulinase bakteri IS_1}

Enzim inulinase adalah salah satu jenis enzim hidrolase. Inulinase merupakan enzim yang dapat menghidrolisis inulin menjadi monomermonomer fruktosa. Enzim Inulinase (Rfruktosidase) bekerja dengan memotong satuan fruktosa dari inulin pada posisi terminal 0-2,1 dan digolongkan sebagai 2,1-8-D-frukto-fruktano hidrolase (EC 3.2.1.7) (Susilowati, 2013).

Berdasarkan hasil penelitian, pada waktu inkubasi 0 jam aktivitas enzim sangat sedikit sehingga tidak menunjukkan adanya aktivitas enzim. Pada waktu inkubasi 0 jam bakteri mulai mengalami fase logaritmik yang ditandai dengan adanya pertumbuhan, sel-sel mulai membelah dan jumlahnya mulai meningkat, namun pada waktu inkubasi ini bakteri belum menghasilkan aktivitas enzim karena belum terlalu banyak menggunakan substrat. Pada waktu inkubasi 4 jam mulai menunjukkan adanya aktivitas enzim yang cukup tinggi yaitu sebesar 0,388 IU dan selanjutnya menghasilkan aktivitas tertinggi pada waktu inkubasi 8 jam yaitu sebesar 0,490 IU. Hal tersebut dikarenakan enzim inulinase telah menghidrolisis substrat inulin menjadi gula reduksi (fruktosa) dalam media produksi dalam jumlah yang cukup banyak. Selain itu, hal ini dapat dikaitkan dengan fase pertumbuhan bakteri dalam media. Pertumbuhan bakteri pada waktu inkubasi 8 jam merupakan puncak dari fase pertumbuhan logaritmik, dimana jumlah sel-selnya meningkat secara logaritma sesuai dengan pertambahan waktu diiringi dengan meningkatnya penggunaan substrat sehingga produksi enzim menjadi sangat optimal. Pembuatan media starter bertujuan sebagai media adaptasi bagi bakteri IS_1 untuk dapat memproduksi enzim inulinase, sehingga ketika dicampurkan ke dalam media produksi bakteri tidak perlu lagi untuk beradaptasi, melainkan langsung dapat menghidrolisis substrat dalam media produksi oleh enzim. Aktivitas enzim pada waktu inkubasi 12 jam menunjukkan adanya penurunan aktivitas yang sangat tajam hingga 0,016 IU, begitu pula pada waktu inkubasi 16, 20 dan 24 jam masih terus mengalami penurunan hingga menunjukkan tidak adanya aktivitas enzim lagi. Penurunan aktivitas tersebut terjadi karena substrat inulin sebagai sumber karbon telah berkurang sehingga enzim inulinase yang diproduksi juga menurun. Selain itu, hal ini dapat dikaitkan dengan fase pertumbuhan bakteri dalam media. Pertumbuhan bakteri pada waktu inkubasi 12 jam mulai memasuki fase stasioner menuju fase kematian, dimana jumlah sel-selnya tetap bahkan menurun diiringi dengan berkurangnya substrat sehingga produksi enzim menjadi tidak optimal. Menurut Wijanarka et al. (2004), sintesis inulinase akan menurun setelah fase stasioner karena jumlah nutrisi dalam medium yang semakin berkurang dan sel mengalami fase kematian.

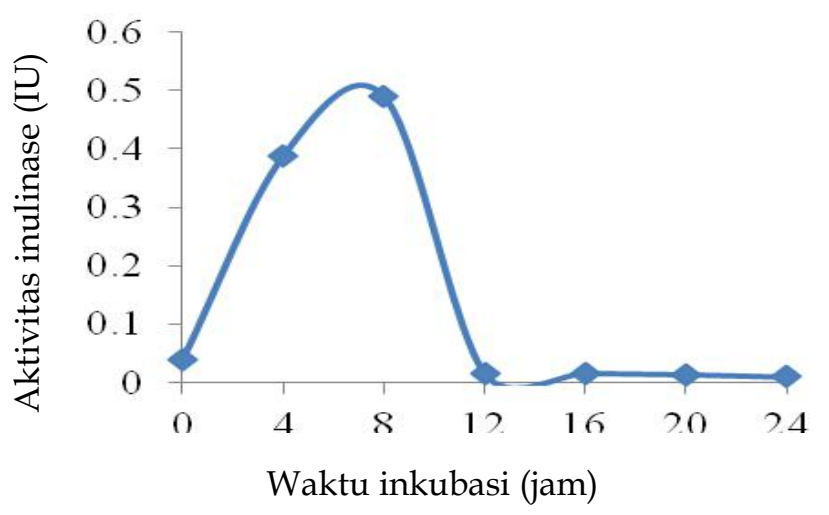

Gambar 2. Profil aktivitas enzim inulinase (IU/ml) isolat bakteri IS_1.

Hasil penelitian menunjukkan bahwa pada jam ke-8 bakteri IS_1 memempunyai aktivitas inulinase yang tertinggi yaitu sebesar 0,490 IU. Oleh karena itu dapat dikatakan bahwa aktivitas tersebut termasuk ke dalam metabolisme primer, sehingga produk enzim tersebut merupakan metabolit primer karena dihasilkan pada fase logaritmik, hal tersebut didukung oleh pendapat dari Wijanarka et al. (2013a) bahwa apabila dikorelasikan dengan pertumbuhan, maka produk enzim yang dihasilkan pada fase log dapat dikatagorikan sebagai metabolisme primer. 


\section{KESIMPULAN}

Berdasarkan penelitian yang telah dilakukan, dapat disimpulkan bahwa hasil pertumbuhan bakteri IS_1 tertinggi terdapat pada waktu inkubasi 8 jam dengan nilai OD sebesar 0,647 dan kecepatan pertumbuhan spesifik $(\mu)$ sebesar 0,02/jam dengan waktu generasi 34,65 jam. Aktivitas enzim tertinggi yang dihasilkan bakteri IS_1 terdapat pada waktu inkubasi 8 jam yaitu sebesar 0,490 IU. Produk enzim inulinase bakteri IS_1 dihasilkan pada fase pertumbuhan logaritmik sehingga digolongkan sebagai metabolit primer.

\section{DAFTAR PUSTAKA}

Dewi, Y. 2016. Prebiotik inulin asal umbi bunga dahlia (Dahlia variabilis) sebagai feed additive untuk meningkatkan ketahanan tubuh broiler. [Skripsi]. Universitas Hasanuddin. Makassar.

Dixon, M and E. Webb. 1979. Enzymes. Logman Group Ltd London.

Gibson, G. R. and N. Delzenne. 2008. Inulin and oligofructose. Nutrition Today. 43(2): 54-59.

Imron, M.F., dan I.F. Purwanti. 2016. Uji kemampuan bakteri Azotobacter S8 dan Bacillus subtilis untuk menyisihkan trivalent chromium $\left(\mathrm{Cr}^{3+}\right)$ pada limbah cair. Jurnal Teknik ITS. 5(1): 5-6.

Massolo, R. 2016. Presentase karkas dan lemak abdominal broiler yang diberi prebiotik inulin umbi bunga dahlia. [Thesis]. Universitas Hasanudin. Makasar.

Ma'aruf, Y. 2011. Penentuan Kadar RBB pada Dye-Inulin secara HPLC melalui Pembentukan Senyawa Dye-Inulin. Fakultas
Matematika dan Ilmu Pengetahuan Alam Universitas Negeri Padang.

Metcalf and Eddy. 2003. Wastewater engineering. Mc.Graw Hill Book Company. New Yor. .

Millis, N.F. and A.J. Pittard. 1992. Microbial Physiology and Genetic of Industry Process. Department of Microbiology. University of Melbourne, Parkville, Victoria, Australia.

Pandiyan, C., V.R. Annal, G. Kumaresan, B. Murugan, and G. Rajarajan. 2012. Effect of incorporation of inulin on the survivability of Lactobacillus acidophilus in synbiotic ice cream. Int Food Res J. 19(4): 1729-1732.

Pirbazari, M., R. Varadarajan, N. Badri, and S.H. Kim. 1996. Hybrid membrane-filtration process for leachate treatment. Water Resource. 11: 2691-2706.

Reiny, S.S. 2012. Potensi Lactobacillus acidophilus ATCC 4796 sebagai biopreservatif pada rebusan daging ikan tongkol. Jurnal IJAS. 2(2): 604-613.

Singh, P. and P.K. Gill. 2006. Production of inulinases: Recent advances. Food Technol. Biotechnol. 44(2): 151-162.

Sumarsih, S. 2003. Mikrobiologi dasar. Jurusan Ilmu Tanah Fakultas Pertanian UPN Veteran. Yogyakarta.

Susilowati, A. 2013. Isolasi kulit umbi dahlia merah (Dahlia spp.) lokal dan aplikasinya sebagai sumber enzim inulinase untuk perolehan serat inulin. Prosiding Seminar Nasional Sains dan Teknologi 4. Universitas Wahid Hasyim. Semarang.

Wijanarka, R.S. Ferniah dan Salamah. 2004. Produksi inulinase Pichia alni DUCC-W4 pada tepung umbi dahlia (Dahlia variabilis Willd) dengan variasi konsentrasi amonium nitrat dan waktu inkubasi. BIOMA. 10(2): 5864.

Wijanarka, E.S. Soetarto, K. Dewi dan A. Indrianto. 2013a. Kinetika pertumbuhan dan produksi inulinase Fusan F7. BIOMA. 15(2): 53-57.

Wijanarka, E.S. Soetarto, K. Dewi dan A. Indrianto. 2013b. Aktivitas inulinase Pichia manshurica dan Fusan F4 pada fermentasi batch dengan umbi dahlia (Dahlia sp.) sebagai substrat. Reaktor. 14(3): 87-192. 